\title{
The Role of Competitive Intelligence in Trade Facilitation in an Emerging Economy
}

\author{
Alexander Maune \\ CEMS, University of South Africa \\ alexandermaune6@gmail.com
}

\begin{abstract}
This article analyzed the role of competitive intelligence in trade facilitation in Zimbabwe, whose economy depends largely on exports of unprocessed minerals and tobacco among others to international markets. This study has been carried out when the country is facing persistent trade deficits as well as a number of trade complexities. This article was informed by both deductive and inductive approaches with an econometric model being developed to analyse the relationship between economic growth (GDP) and trade. A multiple regression analysis was used to measure this phenomenon using secondary data that was extracted from World Bank`s databases for the period 1975-2015. This analysis was then followed by a literature review of some identified peer-reviewed, published articles and documents that necessitated the development of a conceptual framework. The framework complemented the findings of the regression model.The special role of trade in economic development was analyzed using an econometric model with a positive correlation of 0.8045 obtained. An $F$-value equal to 34.86 was also obtained which is much greater than 1 thereby suggesting that the hypothesis $H_{0}$ is false. This was also confirmed by the $p$-value of $0.000000002526<0.05$. The coefficient of determination $R^{2}$, also known as the multiple $R^{2}$, expresses the proportion of total variance explained by the independent variables and in this case an $\mathrm{R}^{2}$ of 0.647224 shows that the model was able to explain approximately $64.72 \%$ of the variation embedded in GDP. Competitive intelligence has been identified as a critical component in trade facilitation with positive effects on growth of trade, economy growth and development. It was also found that competitive intelligence enhances trade facilitation and hence its role cannot be overemphasized. This article is, however, of great significance to policy-makers, researchers and the academia.
\end{abstract}

Keywords: Competitive Intelligence; Trade Facilitation; Emerging Economy; Zimbabwe

\section{Introduction}

Since trade liberalization in the 1990s, Zimbabwe has been hampered by import restrictions and restricted access to international trade. The Zimbabwean economy largely depends on the export of unprocessed minerals and tobacco to China and imports of energy and consumption goods from South Africa among other countries. The country had also suffered from the highest inflation rates worldwide $26470.8 \%$ - November 2007) (Maune, 2014a) before the government abolished the local currency (Zimbabwe dollar) and adopted a multi-currency regime in early 2009. Zimbabwe being a landlocked country has limited water transport services and according to World Bank (2012), it ranked 103 ${ }^{\text {rd }}$ out of 155 countries in trade logistics efficiency. It takes longer time and more costly to export and import in Zimbabwe compared to regional average (World Bank, 2013). It takes 53 days and 71 days to export and import a standard container of goods in Zimbabwe while the regional average stakes almost half, that is, 31 days for export and 28 days for import (World Bank, 2013). The problem lies in the long time to prepare documents, which takes 33 days to export and 42 days to import.

The Zimbabwean economy faces many challenges that include persistent trade deficits. Exacerbating this situation is the slow growth in export of goods and services especially the continuing trade imbalance and the low capacity utilization in the manufacturing sector without mentioning the rampant closure of companies. Makina (2016:22) states that "since 2009 trade deficits have averaged USD3 billion and current account balances as a percentage of GDP have averaged $-22.5 \%$ well over the red flag level of $-5 \%$. These levels of deficit, however, are not sustainable for a dollarized economy."Many African countries are at different stages of implementing trade facilitation measures. These measures aim at reducing microeconomic barriers to trade. Trade facilitation measures (TFMs) seek among other things to reduce complexity, costs, time and levels of error. This will also result in increased transparency and efficiency in many aspects of trade. There is a broad consensus among trade policy-makers that the implementation of TFMs result in significant competitive gains through reduction in transaction costs and improving the business environment thereby attracting many investors and the much needed foreign direct investment. 
African countries are now very keen to explore the possibilities provided by trade facilitation whether in the context of the WTO negotiations, regional or country-specific initiatives (Buyongeand Kireeva, n.d.). These initiatives seek to address both physical infrastructure (roads, ports, telephone connectivity, etc.) and administrative hurdles (Buyongeand Kireeva, n.d.).Trade Facilitation (TF) can help countries to reduce trade costs and increase competitiveness of the private sector (Rippel, 2011). Rippel (2011) argues that despite the reduction in tariffs and improvement in market access many countries and regions in Africa are still lacking regional and global integration. To Rippel (2011), this disconnection can have negative consequences for the economic opportunities of private sector businesses, employees, and consumers. The regional and global disintegration can be resolved through the incorporation of competitive intelligence in international trade issues. International trade calls for an in-depth understanding of international relations. African governments and policy-makers need to appreciate the essence of competitive intelligence $(\mathrm{CI})$ as this is critical in the successful implementation of trade related policies. Despite efforts, some African countries have found it difficult to expand trade and take advantage of preferential market access programs, such as the Everything but Arms (EU) and the African Growth and Opportunity Act (U.S.) due to lack of CI (Rippel, 2011). Several African countries have been successful in expanding trade and exports, nevertheless countries lacking natural resources such as oil, natural gas, and minerals, have found it more difficult to expand exports (Rippel, 2011). While the well-endowed countries have enjoyed success, partly due to high prices for many commodities, they also have struggled to diversify their export-base to avoid being too dependent on a few export products. To Rippel (2011), the risk of drastic price declines might be limited, but the export earnings from the capitalintensive natural resources sector often benefit a small share of the population and do little to provide substantial new job opportunities.

Trade is critical in enhancing access to finance and technology and in overcoming constraints of mostly small domestic markets. It also plays an important role in employment creation. This study is very critical to Zimbabwe in particular and Africa in general given the region's level of economic development and the role that trade can play to facilitate economic development. It must be noted that due to some structural constraints, Zimbabwe is failing to effectively participate in global trade hence the need to analyse the role of $\mathrm{CI}$ in TF. Furthermore, Zimbabwe`s export share against global exports is very low and is concentrated on a few products, primarily raw commodities. Proponents of TF have come up with measures that are critical in removing procedural and institutional bottlenecks that increase transaction costs in trade. Hence the need to examine the role that $\mathrm{CI}$ can play in $\mathrm{TF}$ in order to strengthen the country`s trade capacity towards economic development. CI helps to improve the easy of doing business. With international trade and globalisation, CI has become more important. CI aims to gain strategic advantage (Porter, 1980). It focuses on gathering information on the competition both internal and external (Agarwal, 1993 and Schollhammer, 1994). CI plays a very critical role in TF as it helps policy-makers make informed decisions. Intelligence reduces uncertainty thereby ensuring sustainability. Given the complexity of international trade and markets, this article seeks to examine the role of $\mathrm{CI}$ in TF in Zimbabwe.

Objective and research questions: The main objective of this article is to examine the role of $\mathrm{CI}$ in $\mathrm{TF}$ in Zimbabwe. However, a subordinate objective exists to assist in the appreciation of the primary goal. The objective of this study is as follows;

- To examine the importance of $\mathrm{CI}$ in TF.

The research question was formulated as follows;

- How has CI been of importance in TF in Zimbabwe?

The remainder of this article is structured into four sections as follows: Section 2 outlines the literature review; section 3 explains the methodology used in the analysis; section 4 presents data analysis and interpretation and section 5 conclusion.

\section{Literature Review}

Competitive Intelligence: 'Definitions,' to paraphrase Samuel Johnson (1709-1784), are like watches and none is ever exactly correct. The concept of CI is multifaceted and fuzzy. CI is variously presented as a process, a function, a product, or a mix of all three (Bergeron and Hiller, 2002). Adding to the confusion is the multitude of varying definitions of the term (for examples of definitions, see Bergeron and Hiller, 2002; 
McGonagle and Vella, 2002 and Pellissier and Nenzhelele, 2013). Following the arguments of many different authors cited in Pellissier and Nenzhelele (2013), one is forced to conclude that there is no universally agreed definition of CI. The author adopted Pellissier and Nenzhelele`s 2013 definition for the purposes of this study. To Pellissier and Nenzhelele (2013), CI is a process or practice that produces and disseminates actionable intelligence by planning, ethnically and legally collecting, processing and analyzing information from and about the internal and external or competitive environment in order to help decision-makers in decisionmaking and to provide a competitive advantage to the enterprise [or country]. Moreover, CI should stimulate an organization's creativeness, innovativeness, and willingness to change (Bergeron and Hiller, 2002), in a continuing quest to create an evolving and intelligent organization. (For more detailed analysis of the definition and cycle of CI see Maune, 2014a, b, c, d).

Competitive intelligence in Zimbabwe: $\mathrm{CI}$, as it is known today, is actually an amalgam of disciplines (Juhari and Stephens, 2006). Historical records reveal the important role that intelligence has played in the history of countries (Underwood, 2002). Accordingly, CI evolved from developments in economics, marketing, military theory, information science, and strategic management (Fuld, 1985; Helms, Ettkin, and Morris, 2000; Prescott and Miller, 2001). Intelligence issues are not alien to Zimbabwe as traditional chiefs have been recognized as custodians and fountains of knowledge as they made consultations with their council machinery or court system before taking any decision (Maune, 2014a). CI in Zimbabwe has a long history that can be traced back to the way our ancestors lived although part of this history was not documented as it was passed through oral tradition. However, there is much evidence on the ground through archeological activities to show how intelligence emanated. One is tempted to think that intelligence in Zimbabwe dates even back to the construction of the great monuments like the Great Zimbabwe, by ancestors of the Shona people that started in the $11^{\text {th }}$ century and continued until the $14^{\text {th }}$ century, spanning an area of 722 hectares. Great Zimbabwe is considered the largest in Africa after the Egyptian pyramids (Beach, 1998). The way Great Zimbabwe was built with three distinct architectural groups known as the hill complex, the valley complex and the great enclosure tells the whole story behind the intelligence of the people who built the monuments. Garlake (2002) claims that Great Zimbabwe became a centre for trading which formed part of a trade network linked to Kilwa and extending as far as China. Intelligence can also be traced back to the way the ancestors administer their empires, to the Masvikiros, the rain-making activities at Njelele and Matonjeni at Matopos hill together with many other activities. Zimbabwe has also developed its own intelligence during and after its wars of liberation in 1896-1897 and 1966-1979 as traces of CI in many countries has been linked to the military (Juhari and Stephens, 2006). The above background together with international practices has helped companies to develop their own intelligence strategies for survival (Maune, 2014a). Maune (2014a), however, argues that Zimbabwe is considered to have the most effective and efficient intelligence units in Africa although unauthenticated. However, more recent internal economic events had much impact towards the developed of CI in Zimbabwe.

The important role of competitive intelligence: Theoretical debates have generally focused on the increasing roles and functions of $\mathrm{CI}$ in economic growth. CI has played an intermediation role between economic development and its factors. Degerstedt (2015:5) argues that "the objective of CI is to understand how the surrounding competitive environment will impact an organization - by monitoring events, actors, trends, research breakthroughs, and so forth - in order to be able to make relevant strategic decisions." A major trend in the world today is the increasing competition in global and digitalized markets where the speed of change and innovation is becoming faster than ever before (Degerstedt, 2015). Degerstedt (2015) further argues that this development is fueled by developments in information technology (IT) and is likely to continue for a long time. In order for organizations to keep up with the rapid change, a systematic approach to understand the surrounding world is needed. CI can help provide a better understanding of the global world. However, to Søilen (2017) developments in new technology is also posing a serious threat to companies as today every individual is a potential spy. He further argues that corporate espionage has also become a big problem with its consequences still underestimated. The current information/knowledge generation has placed CI at the center stage of economic growth. Previously, factors such as capital, labor and natural resources were traditionally considered as the only factors which matter for economic growth. However, the technology explosion of the 1990s primarily stimulated the notion of CI as being something entirely new or even revolutionary (Maune, 2014b:100). Maune (2014b:100) further argues that, the emergence of the internet and online databases have offered an almost inexhaustible supply of information 
that has caused information overload in many instances. This has resulted in the development of social competitive intelligence by intelligence practitioners. Calof and Skinner (1999) in Maune (2014d) argue that a country is likely to underperform without an appropriate $\mathrm{CI}$ infrastructure.

Trade Facilitation: As is to be expected, the definition of TF is a highly debated issue in World Trade Organization (WTO). Members have indicated several areas as the prime subject of TF. According to the Kelkar Committee Report, ${ }^{1} \mathrm{TF}$ revolves around the reduction of all the transaction costs associated with the enforcement of legislation, regulation, and administration of trade policies. It involves several agencies such as customs, airport authority, port authority, central bank and trade ministry. The main objective is to reduce the cost of doing business for all parties by eliminating unnecessary administrative burdens associated with bringing goods and services across borders. The means to achieve this objective is the modernization and automation of clearance procedures to established international standards. The EU`s submission ${ }^{2}$ in 1996 defined TF as the simplification and harmonization of trade procedures and of documentation and as standards for computerization or standardized trade procedures. Zimbabwe, being a member of both COMESA and SADC, is therefore centrally located to be part of the on-going process with respect to TF. However, the country has a long history of hampering smooth trading across borders through non-tariff barriers. Its geo-economic centrality in Southern Africa becomes key to TF as well as transit trade along the North-South Corridor (NSC).

Trade Costs in Africa-Why is Trade Facilitation Critical: According to Economic Commission for Africa [ECA] (2013:3), "having a thorough understanding of the pattern and evolution of trade costs is critical to gauge the potential impact of any TF activity for at least four main reasons."ECA (2013:3) provides the reasons as follows, "first, as the existing literature unanimously argues that a decline in trade related costs can significantly boost trade performance, it is straightforward to see that the potential relevance of TF is greater the higher the scope to cut transaction costs. Secondly, and as a corollary of the first point, knowledge of the sources of trade costs is critical in determining which precise TF instrument is likely to have the highest payoff. Thirdly, given that one of the controversial aspects of the proposed Trade Facilitation Agreements is whether or not it would disproportionately facilitate imports, it is important to assess the extent to which imports and exports costs are correlated and why. Fourthly, the pattern of trade-related costs across countries of origin or destination can clearly affect the overall impact of TF on regional integration." CI can be the panacea that provides a better and thorough understanding of these patterns and the evolution of trade costs that is critical in determining the TF activity to be implemented. Without the necessary intelligentsia it becomes a mammoth task for countries to implement the appropriate TF measures.

Table 1: Transaction costs in international trade, regional averages in 2014

\begin{tabular}{|c|c|c|c|c|c|c|}
\hline & $\begin{array}{l}\text { Cost to } \\
\text { export } \\
\text { (US\$ per } \\
\text { container) } \\
\end{array}$ & $\begin{array}{l}\text { Cost to } \\
\text { import } \\
\text { (US\$ per } \\
\text { container) } \\
\end{array}$ & $\begin{array}{l}\text { Documents } \\
\text { to export } \\
\text { (number) }\end{array}$ & $\begin{array}{l}\text { Documents } \\
\text { to import } \\
\text { (number) }\end{array}$ & $\begin{array}{l}\text { Time to } \\
\text { export } \\
\text { (days) }\end{array}$ & $\begin{array}{l}\text { Time to } \\
\text { import } \\
\text { (days) }\end{array}$ \\
\hline Sub-Saharan Africa & 2,201 & 2,931 & 8 & 9 & 31 & 38 \\
\hline East Asia \& Pacific & 868 & 902 & 5 & 6 & 19 & 20 \\
\hline Europe \& Central Asia & 1,663 & 1,822 & 5 & 6 & 18 & 18 \\
\hline Latin America \& Caribbean & 1,287 & 1,666 & 6 & 7 & 17 & 18 \\
\hline Middle East \& North Africa & 1,140 & 1,272 & 6 & 8 & 19 & 23 \\
\hline South Asia & 1,923 & 2,118 & 7 & 8 & 33 & 34 \\
\hline World & 1,560 & 1,877 & 6 & 7 & 22 & 24 \\
\hline OECD members & 1,070 & 1,111 & 4 & 4 & 11 & 10 \\
\hline Zimbabwe & 4,265 & 6,160 & 7 & 9 & 53 & 71 \\
\hline
\end{tabular}

Source: Author (data collected from World Bank`s World Development Indicators)

${ }^{1}$ Chapter 2 of the Kelkar Committee Report.

2Elements of a WTO program on trade facilitation, G/C/W/67, 11 November 1996. 
Table 1 above provides a comparative analysis of the six dimensions of transaction costs at regional level for 2014. The figures reveal that sub-Saharan Africa remain by far one of the region where international trade is most expensive followed by South Asia with Eastern Europe and Central Asia following suit. Zimbabwe proves to be an expensive trading partner with the cost of exporting and importing a standard container averages USD4, 265.00 and USD6, 160.00 respectively. The country`s average time to export and import a standard container of goods averages 53 days and 71 days respectively while, the regional averages are almost its half ( 31 days for export and 38 days for import). The problem lies in the long time to prepare documents, which takes 33 and 42 days. Therefore, internal border agency cooperation and formality of documents need to be improved.

ECA (2013) argues that regional averages could mask, however, significant variability across country, especially in a continent as diverse as Africa; hence it is important to look at a more disaggregated picture. Figure 1, Figure 2 and Table 2 presents a country-by-country analysis of the sources of trade-related transactional costs for exports and imports in Africa for 2014. Starting from the cost to export and import a standard container of goods many African countries proved to be very expensive when compared to the World averages of USD1, 560.00 and USD1, 877.00 for cost to export and import a standard container of goods respectively. Overall, in 2014, 24 out of the 43 African countries shown in Figure 1, Figure 2 and Table 2 exceeded the world average in both the cost of exporting and importing a standard container of goods with Chad leading the list followed by South Sudan, Central African Republic, Zambia and then Zimbabwe. Morocco records the lowest cost to export a container at USD595.00 while Seychelles has the lowest cost to import a container (USD675.00) as of 2014.ECA (2013) states that in 2012 export costs exceeded the world average for 25 of the 51 African countries for which data was available, whilst the time necessary to export surpassed the corresponding world average for as many as 35 African countries. Figure 1, Figure 2 and Table 2 also shows that 10 out of the 43 African countries require less time to export and import as compared to the world averages and these countries are: Egypt, Gabon, Morocco, Mauritius, Senegal, Seychelles, South Africa, Swaziland, Tanzania and Tunisia.

\section{Figure 1: Cost to export and import (USD per container)}

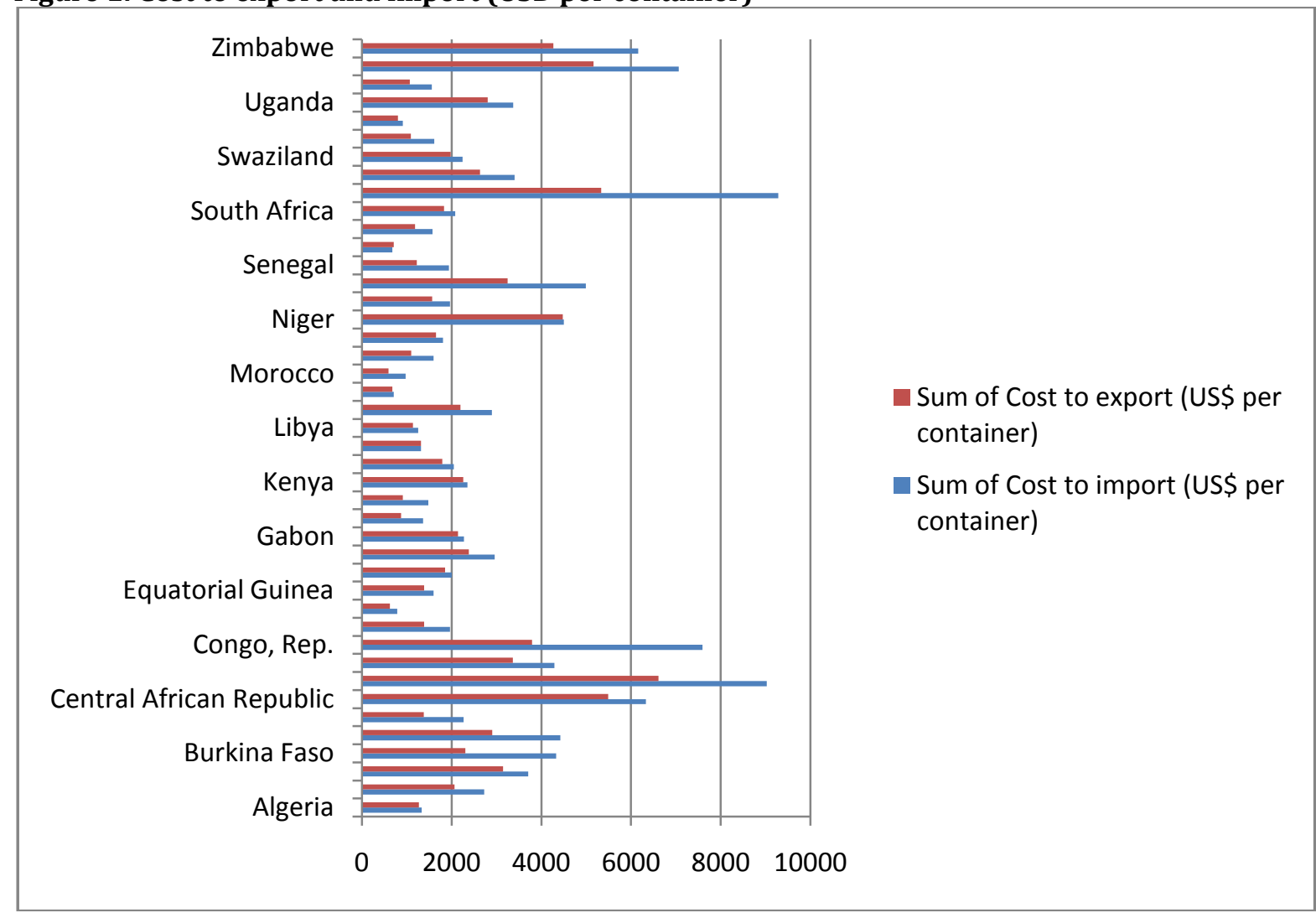

Source: Author (data collected from World Bank`s World Development Indicators) 


\section{Figure 2: Documents (number) and time (days) to export and import}

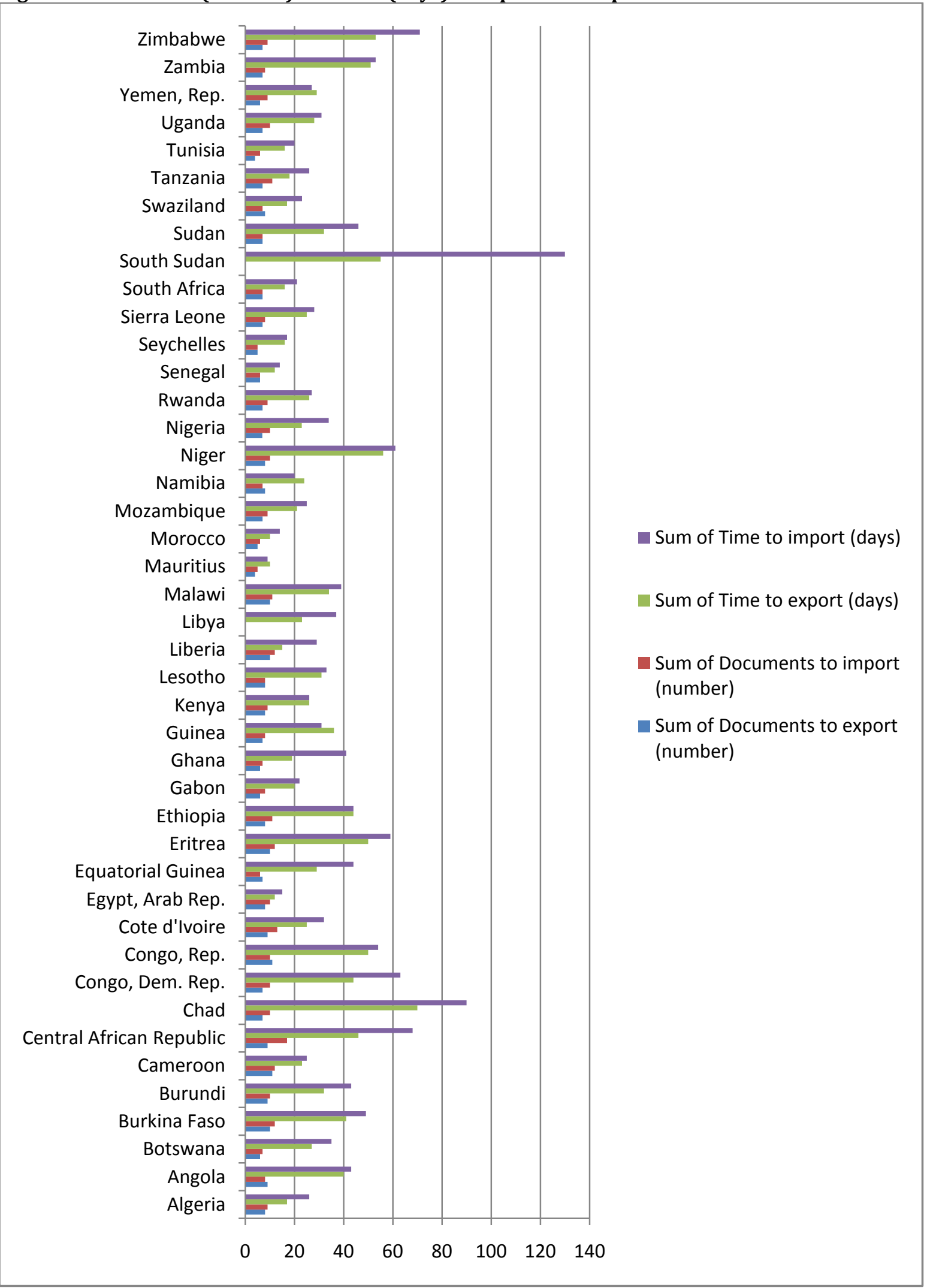

Source: Author (data collected from World Bank`s World Development Indicators) 
Table 2: Transaction costs for exports and imports in African countries in 2014

\begin{tabular}{|c|c|c|c|c|c|c|}
\hline Country & $\begin{array}{l}\text { Cost to } \\
\text { export } \\
\text { (US\$ per } \\
\text { container) }\end{array}$ & $\begin{array}{lr}\text { Cost } & \text { to } \\
\text { import (US\$ } & \text { per } \\
\text { container) } \\
\end{array}$ & $\begin{array}{l}\text { Documents } \\
\text { to export } \\
\text { (number) }\end{array}$ & $\begin{array}{l}\text { Documents } \\
\text { to import } \\
\text { (number) }\end{array}$ & $\begin{array}{l}\text { Time } \\
\text { to } \\
\text { export } \\
\text { (days) } \\
\end{array}$ & $\begin{array}{l}\text { Time } \\
\text { to } \\
\text { import } \\
\text { (days) }\end{array}$ \\
\hline Algeria & 1,270 & 1,330 & 8 & 9 & 17 & 26 \\
\hline Angola & 2,060 & 2,725 & 9 & 8 & 40 & 43 \\
\hline Botswana & 3,145 & 3,710 & 6 & 7 & 27 & 35 \\
\hline Cameroon & 1,379 & 2,267 & 11 & 12 & 23 & 25 \\
\hline Burkina Faso & 2,305 & 4,330 & 10 & 12 & 41 & 49 \\
\hline Burundi & 2,905 & 4,420 & 9 & 10 & 32 & 43 \\
\hline Central African Rep. & 5,490 & 6,335 & 9 & 17 & 46 & 68 \\
\hline Chad & 6,615 & 9,025 & 7 & 10 & 70 & 90 \\
\hline Congo, Dem. Rep. & 3,365 & 4,290 & 7 & 10 & 44 & 63 \\
\hline Congo, Rep. & 3,795 & 7,590 & 11 & 10 & 50 & 54 \\
\hline Cote d'Ivoire & 1,390 & 1,960 & 9 & 13 & 25 & 32 \\
\hline Egypt, Arab Rep. & 625 & 790 & 8 & 10 & 12 & 15 \\
\hline Equatorial Guinea & 1,390 & 1,600 & 7 & 6 & 29 & 44 \\
\hline Eritrea & 1,850 & 2,000 & 10 & 12 & 50 & 59 \\
\hline Ethiopia & 2,380 & 2,960 & 8 & 11 & 44 & 44 \\
\hline Gabon & 2,145 & 2,275 & 6 & 8 & 20 & 22 \\
\hline Guinea & 915 & 1,480 & 7 & 8 & 36 & 31 \\
\hline Ghana & 875 & 1,360 & 6 & 7 & 19 & 41 \\
\hline Kenya & 2,255 & 2,350 & 8 & 9 & 26 & 26 \\
\hline Lesotho & 1,795 & 2,045 & 8 & 8 & 31 & 33 \\
\hline Libya & 1,140 & 1,255 & .. & .. & 23 & 37 \\
\hline Liberia & 1,320 & 1,320 & 10 & 12 & 15 & 29 \\
\hline Malawi & 2,200 & 2,895 & 10 & 11 & 34 & 39 \\
\hline Morocco & 595 & 970 & 5 & 6 & 10 & 14 \\
\hline Mozambique & 1,100 & 1,600 & 7 & 9 & 21 & 25 \\
\hline Namibia & 1,650 & 1,805 & 8 & 7 & 24 & 20 \\
\hline Mauritius & 675 & 710 & 4 & 5 & 10 & 9 \\
\hline Nigeria & 1,564 & 1,960 & 7 & 10 & 23 & 34 \\
\hline Niger & 4,475 & 4,500 & 8 & 10 & 56 & 61 \\
\hline Rwanda & 3,245 & 4,990 & 7 & 9 & 26 & 27 \\
\hline Senegal & 1,225 & 1,940 & 6 & 6 & 12 & 14 \\
\hline Seychelles & 705 & 675 & 5 & 5 & 16 & 17 \\
\hline Sierra Leone & 1,185 & 1,575 & 7 & 8 & 25 & 28 \\
\hline South Africa & 1,830 & 2,080 & 7 & 7 & 16 & 21 \\
\hline South Sudan & 5,335 & 9,285 & .. & .. & 55 & 130 \\
\hline Sudan & 2,630 & 3,400 & 7 & 7 & 32 & 46 \\
\hline Swaziland & 1,980 & 2,245 & 8 & 7 & 17 & 23 \\
\hline Tanzania & 1,090 & 1,615 & 7 & 11 & 18 & 26 \\
\hline Tunisia & 805 & 910 & 4 & 6 & 16 & 20 \\
\hline Uganda & 2,800 & 3,375 & 7 & 10 & 28 & 31 \\
\hline Zambia & 5,165 & 7,060 & 7 & 8 & 51 & 53 \\
\hline Zimbabwe & 4,265 & 6,160 & 7 & 9 & 53 & 71 \\
\hline Yemen, Rep. & 1,065 & 1,560 & 6 & 9 & 29 & 27 \\
\hline
\end{tabular}

Source: Author (data collected from World Bank`s World Development Indicators) 
Table 1, Table 2, Figure 1 and Figure 2 above provides an interesting insight regarding transaction costs for exports and imports in Africa as well as regional averages. Africa`s performance against the world averages as of 2014 data shows that the continent is still very expensive to trade with thereby impacting international trade in a negative way. This situation calls for the incorporation of $\mathrm{CI}$ in the implementation of the most appropriate TF measures. CI becomes a critical component in TF and in international trade. Africa still trails behind its major trading partners in terms of costs, documents required as well as the time required to import and export. Policy-makers need to take these issues serious in order to place Africa on the global map as an influential global player and partner by 2063.

Benefits associated with Trade Facilitation measures: TF can provide important opportunities for Africa by increasing the benefits from open trade, and contributing to economic growth and poverty reduction (Rippel, 2011). Rippel(2011) argues that removing trade barriers has contributed to the expansion of global trade in the decade after the conclusion of the trade negotiations of the Uruguay Round in 1994 and the subsequent establishment of the World Trade Organization (WTO).There is a broad consensus that implementation of TFMs result in significant welfare and competitiveness gains in both developing and developed countries (Gregory, 2009). According to Gregory (2009), "reforming customs procedures, notably through automation, harmonization of information requirements, and risk-assessment methods, directly improves tax returns by enabling effective collection of import duties. Customs reform reduces levels of evasion, under declaration and fraud with customs officials, and allows correct and prompt tax collection. It is generally agreed that the introduction and implementation of most TFMs would entail some start-up costs for the government agencies." The following cost components are likely to be incurred; infrastructure/equipment costs, regulatory costs, human resource costs, institutional/operating costs and political costs (Gregory, 2009).

Rippel (2011) claims that, "the quest for more open trade is not an end in itself but driven by the experience that open trade provides more economic opportunities for people. Producers can offer their goods and services to more customers, and consumers have more choices, lower prices, and access to innovations. Open markets increase prospects of producing and selling new ideas and products locally, regionally and in global markets, which leads to more income opportunities and the improvement of living standards. However, most African countries face considerable challenges to achieving more open trade. One reason is that the costs of trading remain stubbornly high, which prevents potential African exporters competing in global and even in regional markets. Realizing this trend, policy-makers have started incorporating CI to address tradediscouraging non-tariff barriers."TF measures have become a key instrument to create a better trading environment (Rippel, 2011). Rippel (2011) further states that "the international community has acknowledged that for many lower income countries having better market access to industrial countries is insufficient unless the capabilities to trade are addressed as well."

Zimbabwe`s GDP, export and import performance: Zimbabwe`s GDP, export and import of goods and services performance from 1975 to 2015 is shown in figure 3 below. Zimbabwe`s trade performance since 1975 has not been that good with trade imbalances being recorded throughout with the exception of 1976 1978, 1985-1990, 1996, 1999-2001. Significant trade deficits were recorded in 2008 up to 2015 with the highest being recorded in 2013 at USD4.033 billion while 2008 recorded the lowest trade deficit of USD1.174 billion. The main component among the imports has been among other things the importation of second hand vehicles from Japan. The significant surge in trade deficit has been caused by the economic meltdown among other reasons. GDP has shown some fluctuations as well with the lowest being recorded in 1976 at USD4.318 billion while 2014 recorded a high of USD14.197 billion. Since 2009 Zimbabwe`s GDP has been on an upward trend due to some economic recovery measures that were implemented by government chief amongst them being the adoption of the multicurrency regime in 2009 that saw the economy stabilizing. Other reforms included the easy of doing business, monetary and fiscal reforms. Zimbabwe`s economy has shown some great potential of becoming one of the strongest economy in Africa and globally given its abundant natural and intellectual resources. However, a number of challenges have greatly affected the country`s economic recovery path chief among them being the politics of the day as well as corruption. These have greatly affected the country`s investment climate that saw international financiers such as the IMF and World Bank cutting credit lines due to unpleasant relationships. 
Figure 3: GDP, exports and imports of goods and services

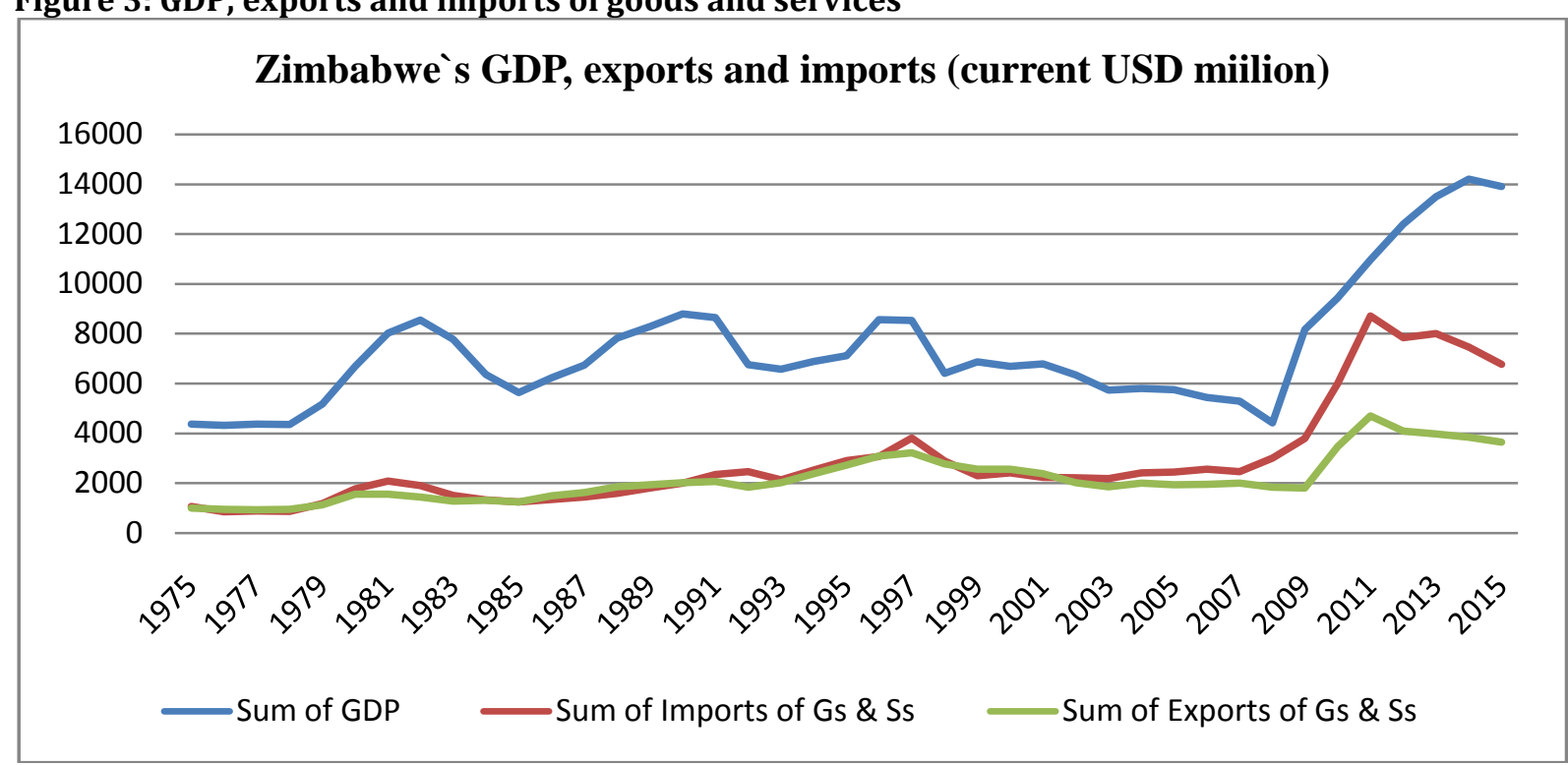

Source: Author (data collected from World Bank`s World Development Indicators)

\section{Methodology}

Research methodology refers to the philosophical framework and the fundamental assumptions of research (Kuhn, 1962). How do we study things and issues? This article was informed by both deductive and inductive approaches. An econometric model was developed first to analyse the relationship between economic growth (GDP) and trade. GDP was the dependent variable while exports and imports of goods and services being the independent variables. The use of a multiple regression model was justified due to its suitability in measuring the relationship between the variables. Secondary data was obtained from the World Bank s Development indicators database for the period 1975 to 2015.This period was chosen as it covers various phases in the economic history of Zimbabwe, that is, before independence, after independence as well as the dollarization period. Data availability was also critical in choosing the period. All the variables were first transformed into natural logarithms before being regressed as the use of natural logarithms has become a standard in econometrics (Brooks, 2008). Brooks (2008:608) argues that, "there are at least three reasons why log transforms maybe useful. First, taking a logarithm can often help to rescale the data so that their variance is more constant, which overcomes a common statistical problem. Second, logarithmic transforms can help to make a positively skewed distribution closer to a normal distribution. Third, taking logarithms can also be a way to make a non-linear, multiplicative relationship between variables into a linear, additive one." The regression equation was expressed in 'double logarithmic form.' According to Brooks (2008), this means that both the dependent and the independent variables were transformed into natural logarithms, thereby rendering the coefficient estimates elasticities. This was done to avoid compromising the significance of the regression model.

A literature review was then conducted on some identified peer-reviewed, published articles and documents on $\mathrm{CI}$ and $\mathrm{TF}$ to necessitate the development of a conceptual framework of $\mathrm{CI}$ and $\mathrm{TF}$ as well as complementing the findings of the regression model. To identify relevant literature, academic databases and search engines were used. Keywords such as, 'competitive intelligence', and 'trade facilitation' were used in search engines to find relevant sources. Reviewing data of existing journal articles was necessary to enhance the generalizability of the findings (Morse, 1999). A qualitative approach was conducted to have a better understanding of the role of CI in TF in Zimbabwe (Du Plooy, 2006; Bless, Higson-Smith and Sithole, 2013; Babbie, 2013 and Du Plooy-Cilliers, Davis and Bezuidenhout, 2014). Literature review was used for its suitability for this article (Light and Pillemer, 1984; Bem, 1995; and Mulrow, 1995). Although there are paradigm wars between purist and pluralist on combining research methods, researchers should forge ahead with what works, because truth is a normative concept - truth is what works (Du Plessis and Dzvimbo, 2014). 
The econometric model takes the following form:

$\ln Y_{t}=\ln \beta_{1}+\beta_{2} \ln X_{2 t}+\beta_{3} \ln X_{3 t}+u_{t}(1)$

Now let $\beta_{1}=\ln \beta_{1}, Y_{t}=\ln Y_{t} X_{2 t}=\ln X_{2 t}$ and $X_{3 t}=\ln X_{3 t}$

$Y_{t}=\beta_{1}+\beta_{2} X_{2 t}+\beta_{3} X_{3 t}+u_{t}$,

$Y_{t}=\beta_{1}+\beta_{2}$ Imports of goods \& services $+\beta_{3}$ Exports of goods \& services $+u_{t}$ (3)

\section{Data Analysis and Interpretation}

Table 4: Regression summary output

\begin{tabular}{|c|c|c|c|c|c|c|c|}
\hline \multicolumn{6}{|c|}{ Regression Analysis } & \multicolumn{2}{|c|}{ Durbin-Watson Test } \\
\hline OVERALL FIT & & & & & & Alpha & 0.05 \\
\hline Multiple R & 0.80450 & & AIC & -133.353 & & & \\
\hline R Square & 0.64722 & & AICc & -132.242 & & D-stat & 0.48503 \\
\hline Adjusted $\mathrm{R}^{2}$ & 0.62865 & & SBC & -128.213 & & D-lower & 1.39922 \\
\hline Standard Error & 0.18986 & & & & & D-upper & 1.60307 \\
\hline Observations & 41 & & & & & sig & yes \\
\hline \multirow[t]{2}{*}{ ANOVA } & & & & Alpha & 0.05 & & \\
\hline & $D f$ & SS & $M S$ & $F$ & $p$-value & sig & \\
\hline Regression & 2 & 2.51324 & 1.25662 & 34.8586 & 2.53E-09 & yes & \\
\hline Residual & 38 & 1.36986 & 0.03605 & & & & \\
\hline \multirow[t]{2}{*}{ Total } & 40 & 3.88310 & & & & & \\
\hline & coeff & std err & tstat & $p$-value & Lower & upper & vif \\
\hline Intercept & 12.4912 & 1.826756 & 6.837939 & $4.08 \mathrm{E}-08$ & 8.793171 & 16.18932 & \\
\hline Imports, Gs\&Ss & 0.29632 & 0.138632 & 2.137475 & 0.039055 & 0.015677 & 0.576969 & 7.836296 \\
\hline Exports, Gs\&Ss & 0.17711 & 0.199695 & 0.886905 & 0.380709 & -0.22715 & 0.581371 & 7.836296 \\
\hline
\end{tabular}

The model obtained thus:

$G D P=12.4912+0.29632$ Import of Gs\&Ss+ 0.17711Exports of Gs\&Ss+ $u_{t}(4)$

"The purpose of regression models, also known as explanatory models, is to identify a functional relationship between the target variable and a subset of the remaining attributes contained in the dataset" (Vercellis, 2009:154). Vercellis (2009:153-154) further argues that, "thus, the goal of regression models is twofold. On one hand, regression models serve to highlight and interpret the dependency of the target variable on the other variables. On the other hand, they are used to predict the future value of the target attribute, based upon the functional relationship identified and the future value of the explanatory attributes." This regression model is more accurate, and therefore more useful from an application standpoint, as the deviation is close to 0 at 0.18986 as shown in table 4 above. The estimator of the standard deviation is, however, referred to as the standard error and it plays a critical role in the determination of the accuracy of a regression model, since it determines the dispersion of the data around the prediction line (Vercellis, 2009). The Cook's distance, was observed as it highlights the presence of abnormal and large values of the residuals. An observation with a Cook's distance greater than 1 is considered abnormal with respect to the regression model (Vercellis, 2009). According to Vercellis (2009), the Cook's distance, however, has a significant influence to the values of the regression coefficients. The results of this model shows the Cook's distance lower than 0.5 for all the observations. Table 4 also provides an $F$-value equal to 34.86 , much greater than 1 , suggesting that the hypothesis $H_{0}$ is false. This is also confirmed by the $p$-value which is less than 0.05 at 0.000000002526 . The 
coefficient of determination $R^{2}$, also known as multiple $R$-squared, expresses the proportion of total variance explained by the predictive variables and in this case an $\mathrm{R}^{2}$ of 0.647224 , shows that the model is able to explain approximately $64.72 \%$ of the variation embedded in the dependent variable. The coefficient estimate for imports of goods and services of 0.296323 shows that a rise in imports of goods and services of $1 \%$ leads on average, everything else being equal, to a rise in GDP of $0.30 \%$. While the coefficient estimate for exports of goods and services of 0.17711 denotes that a $1 \%$ rise in exports of goods and services leads on average to a rise in GDP of $0.18 \%$, holding all other things constant. Exports of goods and services are insignificant towards influencing the GDP as their p-value is greater than 0.05 at 0.38 while imports of goods and services significantly influences GDP as shown by a p-value of 0.039 that is less than 0.05 level of significance.

The results are in line with literature (Abdullahi et al., 2016) though these studies differ on the significance of imports and exports on GDP growth. However, the findings by Zahonogo (2016) suggest that the openness of African economies to international trade should be associated with growth, which is in line with other empirical works. Zahonogo (2016) however, confirms that the relation was not linear, confirming the fragility of the links between trade openness and economic growth for sub-Saharan African countries. To Zahonogo (2016), Sub-Saharan African countries must efficiently control trade openness; particularly import levels, when seeking to boost their economic growth through international trade. In conclusion Zahonogo (2016) suggests that trade openness must be accompanied by complementary policies aimed at encouraging the financing of new investment and enhancing the quality of institutions and the ability to adjust and learn new skills. The findings of this study are also in line with Mangir et al. (2017) `s findings which shows a long-run equilibrium link between international and economic growth in Niger. To Gwaindepi et al. (2014), the relationship between trade and economic growth is strengthened by the stability of the macroeconomic policy since negative macroeconomic drivers such as rising inflation can constrain economic growth. Openness to trade is also deemed to play a crucial role, where reduction and elimination of barriers to trade promote growth in trade and ultimately economic growth (Gwaindepi et al., 2014).

The information provided by the model is very critical for policy-makers as it provides grey areas and gaps that need special consideration and attention. In this case about $35.28 \%$ of the variation in GDP is not being explained by imports and exports hence policy-makers need to find the variables that will fill in the gap. There is therefore need to analyze the role played by $\mathrm{CI}$ in TF to enhance the contribution of exports and imports to GDP. Literature provides that imports and exports play a very critical role in economic growth and development hence the need to strengthen TF through incorporating $\mathrm{CI}$ which is basically the intent of this study. Keho (2017) finds that trade openness has positive effects on economic growth both in the short and long run. Furthermore, Keho (2017)`s results reveal a positive and strong complementary relationship between trade openness and capital formation in promoting economic growth. The results of the econometric model have been complemented by a review of related literature thatexamines the role of $\mathrm{CI}$ in strengthening TF in Zimbabwe. This section presents a discussion of some of the critical findings from literature. The discussion centers on a conceptual framework that was developed to portray the relationship that exists between $\mathrm{CI}$ and TF indicators in Zimbabwe.

Literature has shown that to ensure the strengthening of TF, the Government of Zimbabwe is investing in CI through Zim trade and other private players though at a slower pace. TF measures have become a key policy issue as it seeks to cut the costs of trade, reduces delays at the borders, and makes public agencies dealing with trade more efficient.CI has helped in strengthening TF through provision of intelligence that has helped in streamlining and simplifying exporting and importing procedures, eliminating customs delays and improving customs administration as a way to increase trade flows. Zimbabwe`s participation in a number of bilateral, regional (SADC and COMESA) and multilateral (WTO) trading arrangements where TF is a major outcome has also helped the country to realize the importance of CI in TF. International trade and globalization has called for $\mathrm{CI}$ in providing the much need intelligentsia for policy-makers to strengthen TF at both domestic and international arenas. Without the much needed intelligence it is difficult to implement TF measures. The non-availability of intelligent information has hampered TF the world over. Economic espionage has been at the center stage in international trade and international relations for some time with major economies benefiting much through this illegal activity. The coming in of $\mathrm{CI}$ in international trade has seen a lot of countries making use of their national intelligence to gather the much needed information for competitive advantage in a legal way. 
Zimbabwe has come up with a number of brilliant initiatives to enhance TF but some of them have not been that successful due to lack intelligent information necessary before implementation. This is where CI is critically needed to provide the much needed intelligentsia so that these initiatives benefit the country. CI has benefited Zimbabwe`s trade through the adoption of the Spatial Development Initiatives (SDIs). SDIs play a critical role in addressing regional and international trade bottlenecks as well as promoting regional trade. The SDI concept relies heavily on information availability which is a key objective of CI. All this has been successful through the availability of intelligent information made possible through CI. The SDI concept encompasses the One Stop Border Post (OSBP). Initiatives such as the North South Corridor, Western Cluster Corridors and Eastern Cluster Corridors are critical for regional integration and trade but critical intelligentsia need to be gathered and analyzed first before implementation. In December of 2009, Zimbabwe and Zambia launched the OSBP at Chirundu Border Post with the assistance of COMESA and other Development Agencies. The Chirundu OSBP is the first of its kind in Africa. The country has also made significant strides in the elimination of Non-Tariff Barriers (NTBs) following the establishment of a Monitoring Committee (NMC) in April 2011. The NMC monitors progress on elimination of NTBs experienced at national and tripartite levels as well as reviewing outstanding complaints and other actions taken by line Ministries or Agencies responsible for the enforcement of identified barriers. CI has become very critical for NMC to meet its objectives and goals.

Authorities argue that the role of CI in TF will go a long way in improving Zimbabwe`s trade competitiveness. According to the OECD (2013) report, Zimbabwe matches or exceeds best performance across the sample as regards streamlining of procedures and external border agency cooperation. The country also matches/exceeds the average performance of low income countries in all TFI areas. Performance has improved between 2012 and 2015 in the areas of internal border agency cooperation. Taking into account the trade flow increase and costs reduction potential, Zimbabwe would benefit a lot from $\mathrm{CI}$ as it continue to improve TFIs as promulgated by the OECD. This relationship is depicted in Figure 4 below. In summary, the following conceptual framework in Figure 4 below was developed from literature review. This framework depicts the relationship between $\mathrm{CI}$ and TF measures/indicators.

\section{Figure 4: Relationship between CI and TFIs}

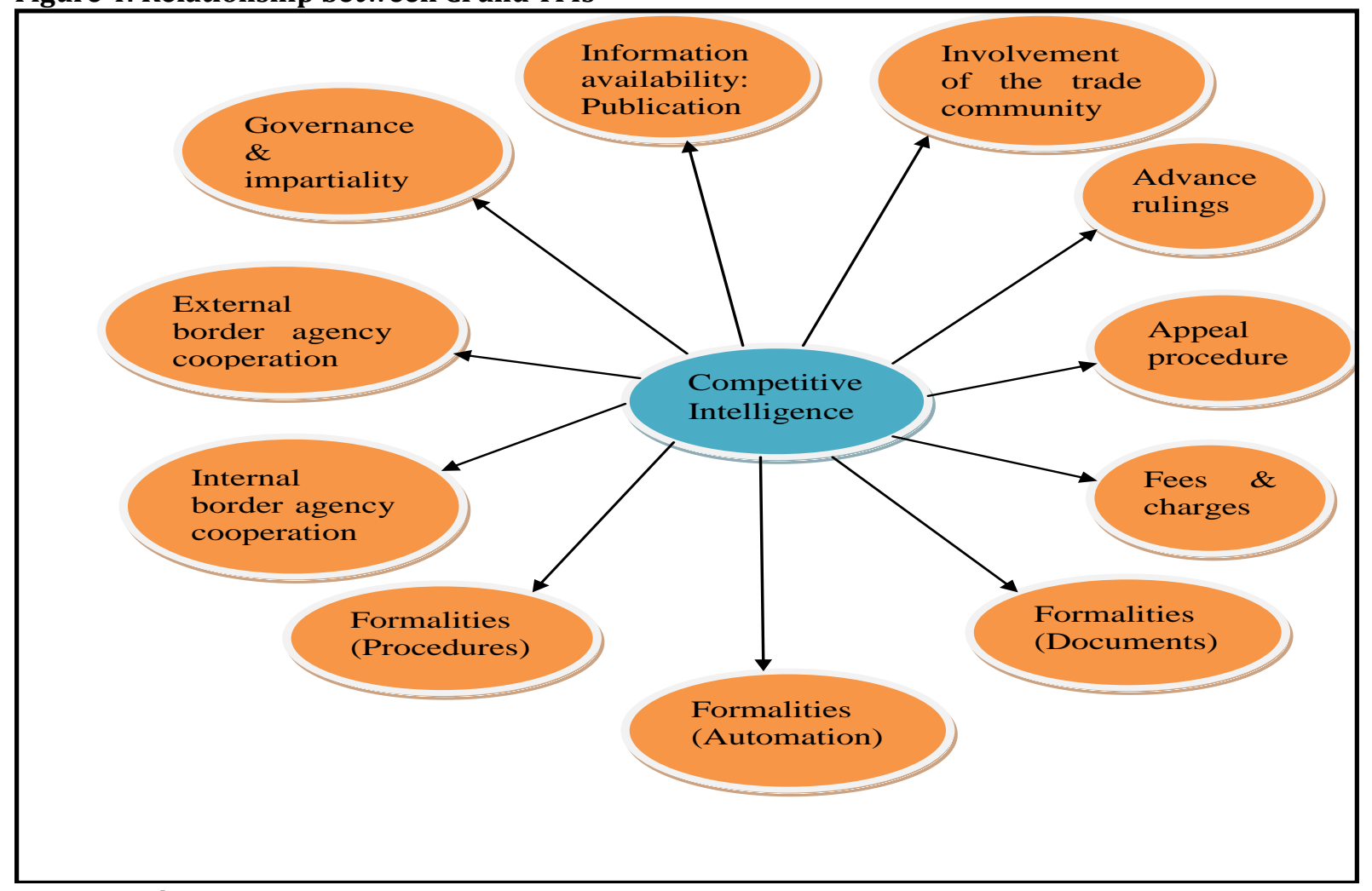

Source: Author 


\section{Journal of Economics and Behavioral Studies (ISSN: 2220-6140)}

Vol. 9, No. 6, pp. 132-148, December 2017

The above conceptual framework can be summarized into a more workable conceptual model that can be further developed and analyzed statistically using a multiple linear regression analysis model. The role of CI can then be analyzed using a quantitative approach where data can be collected using questionnaires from Zimtrade, Zimbabwe National Chamber of Commerce, Confederation of Zimbabwe Industries and the Ministry of trade and commerce. The independent and dependent variables will be as summarized in the conceptual model in Figure 5 below.

Figure 5: Conceptual model showing variables for CI and TF

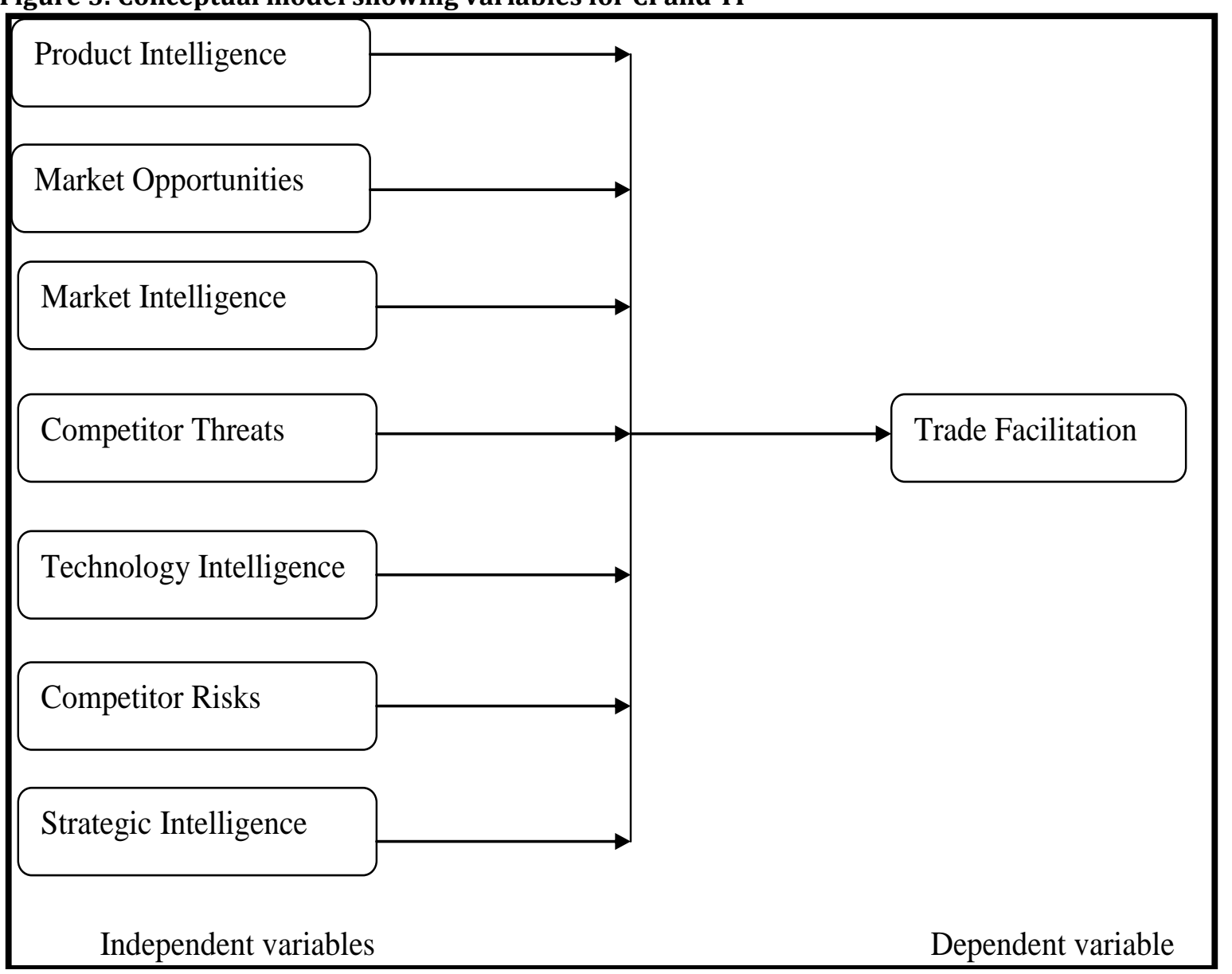

Source: Author

Hypothesis to be tested

$\mathrm{H}_{1}=$ The model is best fit $\quad(p<0.05)$

$\mathrm{H}_{2}=$ The model is not best fit $(p>0.05)$

Alternative hypothesis about coefficient of regression of seven independent variables: Based on the foregoing and the operational conceptual model in Figure 5 above, it can be hypothesized thus,

$\mathrm{H}_{1}=$ Product Intelligence influences TF.

$\mathrm{H}_{2}=$ Market opportunities influence TF.

$\mathrm{H}_{3}=$ Market Intelligence influences TF.

$\mathrm{H}_{4}=$ Competitor threats influence TF.

$\mathrm{H}_{5}=$ Technology Intelligence influences TF.

$\mathrm{H}_{6}=$ Competitor risks influences TF.

$\mathrm{H}_{7}=$ Strategic Intelligence influences TF. 
Data collected through questionnaires will be analyzed by descriptive analysis. The regression equation will be as follows;

$$
Y=\beta_{0}+\beta_{1} X_{1}+\beta_{2} X_{2}+\beta_{3} X_{3}+\beta_{4} X_{4}+\beta_{5} X_{5}+\beta_{6} X_{6}+\beta_{7} X_{7}+\varepsilon(5)
$$

Whereby $\mathrm{Y}=\mathrm{TF}, \mathrm{X}_{1}=$ market intelligence, $\mathrm{X}_{2}=$ product intelligence, $\mathrm{X}_{3}=$ technology intelligence, $\mathrm{X}_{4}=$ strategic alliance intelligence, $X_{5}=$ market opportunities, $X_{6}=$ Competitor threats, $X_{7}=$ Competitor risks, $\beta_{1} \beta_{2}, \beta_{3}, \beta_{4} \beta_{5} \beta_{6}$, $\beta_{7}=$ Coefficients of determination and $\varepsilon=$ error term.

According to Stefanikova et al. (2015), a well-designed system of competitive intelligence can help businesses in the strategic planning process, as well as in determining of intent and ability of its competitors, and also determine the extent of the risks to which enterprise may be exposed. Gross (2000) cited by Stefanikova et al. (2015:210) "confirms that by stating that competitive intelligence in the enterprise serves as a catalyst in the decision making process." Stefanikova et al. (2015) based on the responses from both marketing surveys that had 384 respondents conclude that the enterprises in the Slovak Republic using CI have better competitive position compared to the competitive position of enterprises without CI system. Stefanikova et al. (2015) further found a statistically significant relationship between tendency of market share and duration of $\mathrm{CI}$ in the enterprises in the Slovak republic hence the conclusion that the implementation and use of CI affects the sustainable growth of the enterprises in the Slovak republic. Stefanikova et al. (2015) cite a large number of international researches and studies of $\mathrm{CI}$ that confirms its positive impact (benefit) to business (trade). To Mojarada et al. (2014), the application of CI in export companies can provide a complete picture of current and future competitive status for managers in addition to obtaining the most appropriate strategic decisions, which could ultimately lead to the improved exports in these companies. Mojarada et al. (2014) further argue that the importance of $\mathrm{CI}$ issue becomes enhanced when an organization intends to enter in the global and export markets because the slightest wrong decisions and actions in the international markets can lead the company to the failure. Thus, the CI can lead to making the accurate and timely decisions on the exports policies and ultimately the improvement and development of exports (Mojarada et al., 2014).

\section{Conclusion}

In conclusion, the assessment of the impact of TFMs, both on bilateral trade flows and on trade costs by the OECD in 2013, shows that reforms with the greatest benefit are in the areas of formalities (simplification and harmonization of documents, automation and streamlining of procedures) and information availability. Improving logistics performance and border management is at the core of policies to bolster competitiveness and to boost trade integration. The OECD (2013) reports that trade researches show that improving logistics is where developing countries have the most potential to reduce trade costs. In recent years CI has become an important aspect in TF and the Strategic and Competitive Intelligence Professionals (SCIPs) have been pushing for the integration of $\mathrm{CI}$ in international trade and other sectors. International trade relies much on intelligent information. This information can only be available through CI. CI plays a pivotal role in international trade and TF especially in developed countries. Theoretical debates have generally focused on the increasing roles and functions of CI in economic growth. CI plays an intermediation role between economic development and its factors. The role of CI in Zimbabwe cannot be overemphasized. Taking into account trade flow increase and costs reduction potential, Zimbabwe could draw considerable benefits in terms of trade volumes and trade costs from significant improvements in the areas of appeal procedures and internal border agency cooperation through CI. Continued efforts in the areas of harmonization and simplification of documents and governance and impartiality would also bring further benefits.

A comparative analysis of the six dimensions of transaction costs at regional level for 2014 provides interesting insights with figures revealing that sub-Saharan Africa remain by far one of the region where international trade is most expensive followed by South Asia with Eastern Europe and Central Asia following suit. Zimbabwe proves to be an expensive trading partner with the cost to export and import a container averages USD4, 265.00 and USD6, 160.00 respectively despite her being a landlocked country. The country`s average time to export and import averages 53 days and 71 days against world averages of 22 and 24 with 
sub-Saharan Africa averages of 31 and 38 while the OECD averages 11 and 10 respectively. Documents required to export and import numbered 7 and 9 against world averages of 6 and 7 with OECD averages of 4 and 4 while sub-Saharan Africa averages 8 and 9 respectively. Policy-makers are therefore recommended to consider serious investment in $\mathrm{CI}$ activities so as to enhance trade competitiveness and ensuring meaningful participation in the global trade market. Why investment in CI is critical? As has been shown above CI is very critical in the provision of the much need intelligent information that is required in facilitating the implementation of TFMs which are critical in enhancing international trade. With the main objective of TF being the reduction of the cost of doing business, there is need by all parties involved to eliminate unnecessary administrative burdens associated with bringing goods and services across borders. This can be achieved through a number of measures that involves the simplification and harmonization of trade procedures and of documentation and standards for computerization or standardized trade procedures. This needs to be done a manner that will not pose risks to importing and exporting countries, hence the importance of incorporating CI in implementing these measures. Despite a positive correlation between economic growth and trade, as shown by the results of the model above, TF becomes very critical in enhancing the country`s trade competitiveness in the global arena.

However, international trade has become so complex that the incorporation of CI has taken center stage in international trade. CI has slowly replaced economic espionage that was considered illegal though a number of countries were using it to gain competitive advantage. Policy-makers need also to partner with the private sector and the academia when formulating and implementing policies of this nature and magnitude. It is also recommended that because of the complexity of $\mathrm{TF}$, government departments or organs must be well coordinated to ensure best policies are crafted that enhances the country`s competitiveness globally. Ministries of justice, finance, information, security, trade and commerce, tax authorities, the private sector and the informal cross border traders as well as other interested parties must be well coordinated to ensure best policies are formulated and implemented for the benefit of the country as a whole. CI has been considered a critical component in international trade as it provides the much needed information both internally and externally. This can be done through the involvement of national intelligentsia considering the investment that has been done in these institutions as has become the trend in developed countries. The cooperation between government, private sector as well as the academia is also critical in ensuring the successful implementation of TF measures. This cooperation has become important given the technological developments in international trade as well as the threat that is being posed by cybercrime. All these developments need a coordinated effort from government, private sector as well as the academia for a country to realize the gains of trade.

\section{References}

Abdullahi, A. O., Safiyanu, S. S. \& Soja, T. (2016). International Trade and Economic Growth: An Empirical Analysis of West Africa. IOSR Journal of Economics and Finance (IOSR-JEF), 7(2), 12-15.

Agarwal, S. (1993). Influence of formalization on role stress, organizational commitment, and work alienation of salespersons: A cross-national comparison study. Journal of International Business Studies, 24, 715740.

Babbie, E. (2013). The Practice of Social Research, 13 th Ed. Wadsworth: Cengage Learning, Canada.

Beach, D. (1998). Cognitive Archaeology and Imaginary History at Great Zimbabwe. Current Anthropology, 39, 47.

Bem, D. J. (1995). Writing a review article for Psychological Bulletin. Psychological Bulletin, 118(2), 172-177.

Bergeron, P. \& Hiller, C. A. (2002).Competitive intelligence. Ann. Rev. Info. Sci. Tech., 36, 353-390.

Bless, C., Higson-Smith, C. \& Sithole, S. L. (2013). Fundamentals of Social Research Methods: An African Perspective, 5th Ed. Juta \& Company Ltd.: Cape Town, South Africa.

Buyonge, C. \& Kireeva, I. (n.d.).Trade Facilitation in Africa: Challenges and possible solutions. World Customs Journal, 2(1), 41-54.

Calof, J. \& Skinner, B. (1999). Government's role in competitive intelligence: What's happening in Canada? Competitive Intelligence Magazine, 2(2), 1-5.

Degerstedt, L. (2015). Social competitive intelligence: sociotechnical themes and values for the networking organization. Journal of Intelligence Studies in Business, 5(3), 5-34. 
Du Plessis, G. \& Dzvimbo, K.P. (2014).An Introduction to Mixed Methods Research. Paper presented at a Unisa Research Workshop, 22-23 May, Pretoria, South Africa.

Du Plooy, G. M. (2006). Communication Research. Juta\& Company Ltd.: Cape Town, South Africa.

Du Plooy-Cilliers, F., Davis, C. \& Bezuidenhout, R.M. (2014). Research Matters. Juta \& Company Ltd: Cape Town, South Africa.

ECA (2013).Trade Facilitation from an African Perspective. UNECA, Addis Ababa, Ethiopia, Retrieved 18/10/2016 from http://www.uneca.org.

Fuld, L. M. (1985). Competitive Intelligence. New York: John Wiley \& Sons.

Garlake, P. (2002). Early Art and Architecture of Africa. Oxford: Oxford University Press.

Gregory, D.(2009). The Benefits of Implementing Trade Facilitation Measures in the Hemisphere. A Regional Forum, Canadian Foundation for the Americas (FOCAL), Brazilian Center for International Relations (CEBRI), http://www.focal.ca.

Gross, M. (2000). Competitive Intelligence: A Librarian's Empirical Approach. Searcher: The Magazine for Database Professionals, 8, 70-76.

Gwaindepi, C., Musara, M. \& Dhoro, N.L. (2014). Relationship between International Trade and Economic Growth: A Cointegration Analysis for Zimbabwe. Mediterranean Journal of Social Sciences, 5(20), 621627.

Helms, M. M., Ettkin, L. P. \& Morris, D. J. (2000). In -Security: the pillaging of corporate America. Competitive Intelligence Review, 11, 93-106.

Juhari, A. S. \& Stephens, D. (2006). Tracing the Origins of Competitive Intelligence Throughout History. Journal of Competitive Intelligence and Management, 3(4).

Keho, Y. (2017). The impact of trade openness on economic growth: The case of Cote d'Ivoire. Cogent Economics \& Finance, 5, 1-14.

Kuhn, T. S. (1962). The Structure of Scientific Revolutions. Chicago: University of Chicago Press.

Light, R. \& Pillemer, D. (1984). Summing Up: The Science of Reviewing Research. Cambridge: MA, Harvard University Press.

Makina, D. (2016). Study on Zimbabwe's Macroeconomic Stability and Policy Options. Confederation of Zimbabwe Industries (CZ I) and the National Economic Consultative Forum (NECF) to the USAIDStrategic Economic Research and Analysis (SERA) Program. Program under Contract No.USAID-613C-11-00001.

Mangir, F., Acet, H. \& Baoua, M.M.A. (2017). An Empirical Analysis on the Relationship between Trade Openness and Economic Growth in Niger.EconWorld2017@Paris Proceedings, July 25-27, 2017; Paris, France.

Maune, A. (2014a). A conceptual analysis of the role of competitive intelligence in Zimbabwe`s banking sector. Journal of Governance and Regulation, 3(4), 125-137.

Maune, A. (2014b). Competitive Intelligence as an Important Contributor to the Growth of Banks: A Zimbabwean Perspective. Journal of Governance and Regulation, 3(3), 98-112.

Maune, A. (2014c). Competitive Intelligence as an Enabler for Firm Competitiveness: An Overview. Journal of Governance and Regulation, 3(2), 29-42.

Maune, A. (2014d). Competitive Intelligence in South Africa: A Historiography. Journal of Corporate Ownership and Control, 11(4), 635-641.

McGonagle, J. J. \& Vella, C. M. (2002). Bottom line competitive intelligence. Westport: Quorum Books.

Mojarada, S. Y. R., Zangeneha, G. H. K. \& Azada, N. (2014).The role of competitive intelligence on improving exports. Management Science Letters, 4, 2273-2284.

Morse, J. M. (1999). Qualitative Generalizability. Qualitative Health Research, 9(1), 5-6.

Mulrow, C. D. (1995). Rationale for systematic reviews. In: Chalmers, I. and Altman, D. (Eds) Systematic Reviews. London: BMJ Publishing Group.

OECD. (2013). Trade Facilitation Indicators: The Potential Impact of Trade Facilitation on Developing Countries' Trade for 107 countries outside the OECD area, Trade Policy Paper No. 144, OECD.

Pellissier, R. \& Nenzhelele, T. E. (2013). Towards a universal definition of competitive intelligence: SA Journal of Information Management, 15(2), Art. Number 559, 7 pages. Http://dx.doi. org/10.4102/sajim.v15i2.559.

Porter, M. E. (1980). Competitive Strategy: Techniques of Analyzing Industries and Competitors. New York: The Free Press. 


\section{Journal of Economics and Behavioral Studies (ISSN: 2220-6140)}

Vol. 9, No. 6, pp. 132-148, December 2017

Prescott, J. E. \& Miller, S. H. (2001). Proven Strategies in Competitive Intelligence. New York: John Wiley \& Sons, Inc.

Rippel, B. (2011). Why Trade Facilitation is Important for Africa, Africa Trade Policy Notes, Note No. 27, Multi-Donor Trust Fund for Trade and Development.

Schollhammer, H. (1994). Strategies and methodologies in international business and comparative management research. Management International Review, 34, 5-21.

Søilen, K. S. (2017). Why care about competitive intelligence and market intelligence? The case of Ericsson and the Swedish Cellulose Company. Journal of Intelligence Studies in Business, 7(2), 27-39.

Stefanikova, L., Rypakova, M. \& Moravcikova, K. (2015). The impact of competitive intelligence on sustainable growth of the Enterprises. Procedia Economics and Finance, 26, $209-214$.

Underwood, J. (2002). Competitive Intelligence: Oxford: Capstone Publishing.

Vercellis, C. (2009). Business Intelligence: Data Mining and Optimization for Decision Making. UK: John Wiley \& Sons, Ltd.

World Bank. (2012). Logistics Performance Index (LPI), http://siteresources.worldbank.org/trade/Resources/239070-1336654966193/LPI_2012_final.pdf.

World Bank. (2013). Doing Business 2013: Smarter Regulations for Small and Medium-Size Enterprises. Washington, D.C.: World Bank Group. DOI: 10.1596/978-0-8213-9615-5.

Zahonogo, P. (2016). Trade and economic growth in developing countries: Evidence from sub-Saharan Africa. Journal of African Trade, 3, 41-56. 